\title{
Acute toxicity of neurotoxin-producing Raphidiopsis (Cylindrospermopsis) raciborskii ITEP-A1 (Cyanobacteria) on the neotropical cladoceran Macrothrix spinosa
}

\author{
Santos, G.S.D., Vilar, M.C.P. \& Azevedo, S.M.F.O. \\ Laboratory of Ecophysiology and Toxicology of Cyanobacteria, Carlos Chagas Filho Institute of Biophysics, Federal University \\ of Rio de Janeiro, Rio de Janeiro, 21949-902, Brazil.
}

Received December 12, 2019; Accept February 12, 2020

\begin{abstract}
Cyanobacterial blooms are recurrent phenomena in several water bodies, mostly eutrophic. They are considered a public health problem, especially considering harmful species like Raphidiopsis raciborskii, a bloom-forming cyanobacteria recorded as a producer of neurotoxic and cytotoxic alkaloids. The present study aimed to assess the acute toxicity of a saxitoxin-producing strain Raphidiopsis raciborskii ITEP-A1 on the zooplankter Macrothrix spinosa. Cladoceran clones isolated from an eutrophic system with cyanobacterial blooms records and an oligotrophic one with no bloom record; both from Pernambuco (Northeastern Brazil), were tested for $R$. raciborskii ITEP-A1 toxicity. Acute toxicity assays were carried out with newborns $(<24 \mathrm{~h}, \mathrm{n}=10)$ and the animals were exposed to three concentrations of cyanobacterial cell biomass $\left(\mu \mathrm{gC} \mathrm{L}^{-1}\right)$. Quantification of saxitoxins (STX and neoSTX) was done by high-performance liquid chromatography coupled with fluorescence detector (HPLC-RF). The $\mathrm{EC}_{50}(48 \mathrm{~h})$ for the Duas Unas and Prata clones were 359 and $189 \mu \mathrm{gC} \mathrm{L}^{-1}$, respectively. Obtained results showed that $M$. spinosa Prata was more sensitive to $R$. raciborskii than Duas Unas, reinforcing the importance of analyzing the previous life history of the test organisms regarding their native environments. However, both clones demonstrated high sensitivity to $R$. raciborskii, which enhances their potential for biomonitoring toxic cyanobacterial blooms in tropical reservoirs.
\end{abstract}

Keywords: Cyanotoxin, tropical, zooplankton

\section{INTRODUCTION}

Widespread pollution from human activity followed by the eutrophication of water bodies has continuously increased the occurrence of cyanobacterial blooms, a worldwide phenomenon and environmental issue. Aquatic environments that are rich in nutrients, particularly nitrogen and phosphorus, are directly connected to the prevalence of blooms, however, it is not the only factor influencing the predominance of cyanobacteria. Rising $\mathrm{CO}_{2}$ levels and global warming are also believed to favor harmful cyanobacterial blooms (Paerl \& Huisman, 2009), increasing their frequency, intensity and duration in many ecosystems all over the world (Huisman et al., 2018).

Some of the most recorded bloom- or mats-forming cyanobacterial genera are Planktothrix, Microseira (syn.
Lyngbya and Plectonema), Dolichospermum, Microcystis and Raphidiopsis (formely Cylindrospermopsis) (Mowe et al., 2015). The latter is commonly found in East and Southeast Asia, Australia and South America, with difference in the type of toxin reported by their isolated strains - for instance, while Raphidiopsis in Australia, East and Southeast Asia produces cylindrospermopsins (CYNs), in South America isolated strains from that species are reported to produce saxitoxins (STXs) (Antunes et al., 2015; Burford et al., 2016; Mowe et al., 2015). The later are a group of neurotoxic carbamate alkaloids which act as ionic channel blockers and affect the nervous system, leading to paralysis and death (Wiese et al., 2010). These toxins are also produced by some genus of eukaryotic marine dinoflagellates such as Alexandrium which concerns due to forming red tides and compromising seafood in marine and coastal ecosystems (Anderson et al., 2012). 
In freshwater systems saxitoxins are usually associated to Raphidiopsis raciborskii (Woloszynska) Aguilera, Berrendero Gómez, Kastovsky, Echenique \& Salerno (basionym Cylindrospermopsis raciborskii (Woloszynska) Seenayya \& Subba Raju) (Aguilera et al., 2018) which is an important bloom-forming and toxin-producing filamentous cyanobacteria, predominant in Brazilian aquatic environments (Bouvy et al., 2001; Soares et al., 2013; Guedes et al., 2018). Its presence in water bodies poses risks to endemic organisms by ingestion of cells or absorption of toxin dissolved in water (Costa et al., 2013), as well as might impact public health by compromising water supply and fish.

Some studies have shown that cyanobacteria exert a variety of effects on zooplankon, such as decrease in survivorship, growth and reproduction (Costa et al., 2013; Ferrão-Filho et al., 2011; Lürling, 2003; Vilar et al., 2014). These effects, however, vary according to the zooplankton species. Some have developed, throughout life history, the ability to coexist with certain species of cyanobacteria. On the other hand, reports suggest that cyanobacteria might have resistance to predation by zooplankton; specifically when there is dominance of $R$. raciborskii in a water body, there is inhibition of the growth of zooplankton as they have difficulty using the large filaments and colonies of cyanobacteria as food (Leonard \& Pearl, 2005; Havens \& East 2006).

Although saxitoxins are potent paralyzing alkaloids and feeding inhibitors, studies suggest they present low lethality effects in invertebrates (Ferrão-Filho et al., 2013). The immobilizing effect of the toxin affects the movements of cladocerans by paralyzing their swimming appendages, but once they are still able to filter-feed even with immobilized limbs they do not suffer from starvation nor respiratory arrest. Thus, as observed by Costa et al. (2013) and Ferrão-Filho et al. (2010), the continuous filtration of food particles whilst paralyzed allows the organisms to survive for long periods. Nevertheless, there is still a lack of research on the effects of STXs on tropical freshwater zooplankton.

Daphnia spp. are among the most commonly used organisms in freshwater quality monitoring programs (ABNT, 2016; USEPA, 2002). Nowadays, most ecotoxicological research in tropical environments are conducted with acclimated exotic cladoceran species from temperate regions, such as Daphnia similis Claus, 1876 and Daphnia magna Straus, 1820 . In the other hand, very few studies are carried out with native ones (Freitas \& Rocha, 2011), therefore, there is a growing preference for using native species on ecotoxicological assessments, as they are more representative of the environment and local-species sensitivity.

On that context, Macrothrix appears to be a potential organism to be used in ecotoxicological assays, although studies on cladocerans from the family Macrothricidae are still incipient. Available data on sensitivity are on the species Macrothrix elegans Sars, 1901 and Macrothrix flabelligera Smirnov, 1992 that have shown potential as suitable testorganisms for a variety toxicity tests (Araújo et al., 2008; Moreira et al., 2014; Moreira et al., 2017). These animals' adaptability, short life cycle and easy maintenance in laboratory facilitate their choice as potential biomonitors for tropical aquatic systems. Species in this genus are described as having an oval body in lateral view, a dilated antennule being identified by the serrations along the dorsal part of its valve (Fuentes-Reinés et al., 2015; Fuentes-Reinés et al., 2018).

Although there is an apparent lack of in-depth studies regarding the tropical species, Macrothrix spinosa King, 1853 is reportedly well-distributed in South American water bodies (Fuentes-Reinés et al., 2018; Sousa et al., 2018). M. spinosa is often presented as synonym of Macrothrix squamosa Sars, 1901. This synonymy is based on superficial characteristics, such as the aspect of the carapace, antennule, and post abdomen (Elmoor-Loureiro, 2007). In contrast, recent studies suggest that Macrothrix spp. tend to have continental or regional distribution, which indicates that $M$. spinosa originally described from Australia, and its congener $M$. squamosa might be different species (Elmoor-Loureiro, 2007; Fuentes-Reinés et al., 2015; Fuentes-Reinés et al., 2018). Regardless, further revision is important to know the diversity of potentially sensitive species on water biomonitoring. Thus, the present study aimed to evaluate the toxicity of a neurotoxin-producing Raphidiopsis raciborskii on the cladoceran Macrothrix spinosa. Moreover, this is the first report of the effects of a saxitoxin-producing cyanobacteria on that zooplankton species. Therefore, the findings may contribute to the knowledge on the potential of a (sub)tropical zooplankton as a tool on the biomonitoring of freshwaters.

\section{MATERIALS AND METHODS}

\section{Cultivation and maintenance of organisms}

The cyanobacterial strain used in this study was a saxitoxin-producing Raphidiopsis raciborskii ITEP-A1 which was isolated from Riacho dos Paus reservoir located in Arcoverde, countryside of Pernambuco state, Brazil. The culture were maintained in ASM-1 (Gorham et al., 1964) medium under initial $\mathrm{pH} 8.0$, controlled temperature $\left(24^{\circ} \mathrm{C}\right.$ $\pm 1)$ and $12 \mathrm{~h}$ dark:light cycle under light intensity $(50 \mu \mathrm{mol}$ $\mathrm{m}^{-2} \mathrm{~s}^{-1}$ ). Culture samples were collected for acute toxicity tests and toxin analysis during exponential growth phase (about 8 days).

Two clones of the cladoceran $M$. spinosa isolated from Prata and Duas Unas reservoirs (Pernambuco, Brazil) were used in this study. Duas Unas is known as a eutrophic water body with previous report of cyanobacterial blooms (Bittencourt-Oliveira et al., 2014; Lorenzi et al., 2018). On the other hand, Prata reservoir is an oligotrophic water body with no previous cyanobacterial bloom report (Almeida et al., 2012).

Zooplankton samples were collected with plankton net (60 $\mu \mathrm{m}$ mesh-size) in the littoral zone of the waterbodies. Animals were anaesthetized with carbonated water $(1: 20 \mathrm{v} / \mathrm{v})$, sorted and disposed in Petri dish where parthenogenetic females of $M$. 
spinosa were isolated under stereoscope and kept in laboratory during several generations. Adults of $M$. spinosa ranged from 0.943-0.961 mm. Animals were cultured in artificial RT culture medium (Tollrian, 1993) with $20 \%$ mineral water enriched with commercial humic extract Microbe Lift ${ }^{\circledR} 0.1 \%$ (approximately $2.25 \mathrm{mg} \mathrm{L}^{-1}$ dissolved carbon content). They were kept under a controlled temperature of $24 \pm 1{ }^{\circ} \mathrm{C}, 12 \mathrm{~h}$ dark:light cycle and fed by mixed cell suspension of green algae Selenastrum capricornutum Printz and Ankistrodesmus stipitatus Komárková-Legnerová at a final biomass $1 \mathrm{mgC} \mathrm{L}^{-1}$.

\section{Cyanobacterial cell biomass measurements}

R. raciborskii ITEP-A1 biomass $\left(\mu \mathrm{gC} \mathrm{L}^{-1}\right)$ was estimated according to Rocha \& Duncan (1985) using the mean trichome volume $\left(\mu \mathrm{m}^{3}\right)$ (Hillebrand et al., 1999) after measuring 50 units, and estimated using trichome density from FuchsRosenthal chamber counting.

\section{Acute toxicity test}

To evaluate $R$. raciborskii ITEP-A1 impact on cladocerans' mobility both clones of $M$. spinosa were exposed to different biomass concentrations, with maximum concentration defined after preliminary acute toxicity test.

Tests were carried out with 10 newborns $(<24 \mathrm{~h})$ of each M. spinosa clone in triplicates. The neonates were put in test tubes containing $25 \mathrm{~mL}$ of different concentrations of $R$. raciborskii ITEP-A1 biomass: 150, 300 and $500 \mu \mathrm{gC} \mathrm{L}{ }^{-1}$, and a control which consisted of cyanobacteria-free culture media. Test organisms were exposed to cyanobacterium for $48 \mathrm{~h}$. After incubation period, the number of immobile individuals in each concentration as well as in the control was recorded for estimative of half maximal effective concentration $\left(\mathrm{EC}_{50}\right.$ 48h) using the Trimmed Spearman-Karber method (Hamilton et al., 1977).

\section{Bibliographic survey of cladoceran sensitivity to saxitoxin- producing cyanobacteria}

It was performed a bibliographic survey about published articles on acute toxicity assay experiments testing the effects of saxitoxin-producing cyanobacteria on cladocerans. Previous toxicity studies, published between 1990 and September 2019, were consulted in the database Web of Science using the following keywords and combinations: bioassay and cyanobacteria (456 articles); cyano* and toxicity and Cladocera (16 articles); neurotoxicity and cyanobacteria (73 articles); saxitoxin and cyanobacteria and Cladocera (3 articles); Macrothrix and toxicity (6 articles).

Aiming to compare our results to the available literature on cladoceran sensitivity to saxitoxin-producing cyanobacteria, the publications were filtered based on the following criteria: 1) the study assessed the acute toxicity of saxitoxin-producing $R$. raciborskii on Cladocera; 2) animals were exposed to intact cyanobacterial cell (or fresh biomass); 3 ) half maximal effective concentration values in cell density $\left(\right.$ cell $\mathrm{mL}^{1}$ ) or biomass $\left(\mu \mathrm{gC} \mathrm{L}^{-1}\right)$.

\section{Saxitoxins extraction and analysis by HPLC-RF}

Saxitoxins extraction from cell biomass were performed using $0.5 \mathrm{M}$ acetic acid. After centrifuging $(22,000 \mathrm{x} \mathrm{g})$, supernatant was collected and filtered through $0.22 \mu \mathrm{m}$ Millex (Millipore) prior to injection. Chromatographic analyses were performed on a Shimadzu HPLC using a silica-based reverse phase column and separations were carried out under specifics mobile phases for non-sulfated saxitoxins (saxitoxin and neosaxitoxin) (hereafter STX and neoSTX) coupled to postcolumn oxidation as described in (Oshima, 1995). Fluorescent saxitoxins derivates were detected using a Shimadzu RF10Axl fluorometric detector with excitation at $330 \mathrm{~nm}$ and emission at $390 \mathrm{~nm}$. Toxins were identified and quantified by comparison with known retention times and integrated areas of standards, respectively. The standards of saxitoxins were purchased from Institute for Marine Bioscience, National Research Council of Canada (Halifax, Canada). Data were shown as total saxitoxin (neo-saxitoxin and saxitoxin) quota per biomass unit $\left(\mathrm{ngSTX}_{\mathrm{total}} / \mu \mathrm{gC}\right)$.

\section{Statistical analysis}

To identify any significant difference in the mean number of affected individuals, the one-way analysis of variance (ANOVA) was used with post hoc Dunnet test in order to ascertain the lowest-observed-adverse-effect level. All statistical analyses were performed using the software SigmaPlot 11.0 and attending the basic premises of the abovementioned tests.

\section{RESULTS}

\section{Cyanobacterial measurements and toxin content}

The average length and width of filament obtained was, respectively, $78.38( \pm 38.91) \mu \mathrm{m}$ and $2.99( \pm 0.58) \mu \mathrm{m}$ resulting in an average trichome volume of $550.35 \mu \mathrm{m}^{3}$ and biomass value of $108,988.601 \mu \mathrm{gC} \mathrm{L} \mathrm{L}^{-1}$. The Total saxitoxin concentration normalized by trichome biomass was 0.2 $\operatorname{ngSTX}_{\text {total }} \mu \mathrm{gC}^{-1}$.

\section{Acute toxicity of R. raciborskii on M. spinosa}

In the acute bioassays, the effects of $R$. raciborskii ITEP-A1 characterized by paralysis of swimming appendages was noticed in both clones. After $24 \mathrm{~h}$ of exposure to the cyanobacterium, all replicates already presented immobile organisms in all concentrations of biomass (data not shown). After $48 \mathrm{~h}$ of exposure that number grew, as the effects of the cyanobacteria affected in more individuals. The immobilization effect was higher with the higher concentrations of cyanobacterial biomass $\left(500 \mu \mathrm{gC} \mathrm{L}^{-1}\right)$ (Figure 1). 

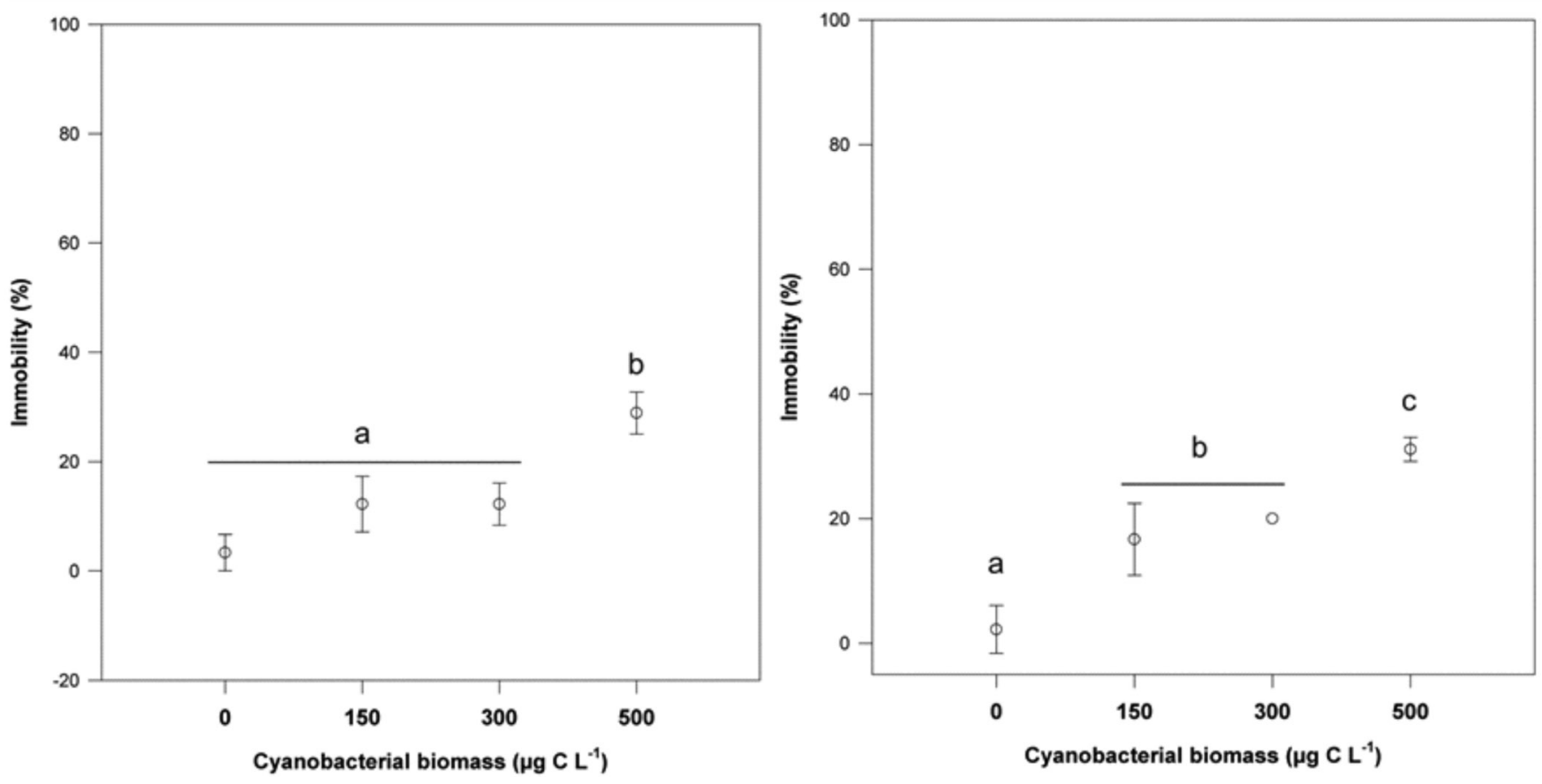

Figure 1. Dose-response of Macrothrix spinosa, clones (A) Duas Unas and (B) Prata under acute exposition to toxic Raphidiopsis raciborskii ITEP-A1. Letters $=$ Significant difference compared to the control (Dunnett, $p<0.05$ ), representing the lowest-observed-adverse-effect.

The lowest-observed-adverse-effect concentrations were equal to or above $150 \mu \mathrm{gC} \mathrm{L} \mathrm{L}^{-1}$ for Prata and $300 \mu \mathrm{gC} \mathrm{\textrm {L } ^ { - 1 }}$ for Duas Unas $M$. spinosa clones (Dunnett, $p<0.05$ ). As showed in Table 1, $\mathrm{EC}_{50}(48 \mathrm{~h})$ for Duas Unas was $359 \mu \mathrm{gC} \mathrm{L} \mathrm{L}^{-1}$, approximately two times higher than the $\mathrm{EC}_{50}(48 \mathrm{~h})$ for Prata, evidencing that individuals originated from Prata reservoir show more sensitivity to $R$. raciborskii ITEP-A1 than the organisms from Duas Unas reservoir.

\section{Bibliographic survey}

When analyzed the bibliographic survey it was found 456 articles when used the terms bioassay and cyanobacteria, and 73 articles to neurotoxicity and cyanobacteria. The most specific the keywords, less articles were found: cyano* and toxicity and cladocera (16 articles); saxitoxin and cyanobacteria and cladocera (3 articles); Macrothrix and toxicity ( 6 articles). After screening, only 3 papers out of $>400$ publications reported data that fitted the established criteria and presented $\mathrm{EC}_{50}$ values that were then compared to those of the present study, as summarized in the Table 2.

\section{DISCUSSION}

In the present study a tropical zooplankton species $M$. spinosa showed to be sensitive to ecologically relevant concentrations of saxitoxin-producing cyanobacteria, regarding its potential on biomonitoring cyanobacterial blooms in tropical water bodies.

When comparing to previous toxicity studies of STXproducing $R$. raciborskii strains, the $\mathrm{EC}_{50}(48 \mathrm{~h})$ values to $M$. spinosa clones Duas Unas $359 \mu \mathrm{gC} \mathrm{L}^{-1}\left(\sim 3.930\right.$ cell $\left.\mathrm{mL}^{1}\right)$ and Prata $189 \mu \mathrm{gC} \mathrm{L}^{-1}\left(\sim 2.607\right.$ cell $\left.\mathrm{mL}^{1}\right)$ were both similar or dissonant to those with standard cladocerans, such as $D$. similis. Also, although M. spinosa has not yet been standardized regarding acute toxicity tests, the species presents similarities with standard test-organisms. For instance, data presented by Zagatto et al. (2012) demonstrated different sensitivities in relation to our findings $-D$. similis exposed to $R$. raciborskii T2 strain showed less sensitivity when compared to our data, while for the T3 strain the daphnid showed more sensitivity. The same was reported by Ferrão-Filho et al. (2014), where $\mathrm{EC}_{50}$ values for $D$. similis exposed to the strain $R$. raciborskii CYRF01 evidenced more sensitivity than our findings. In contrast, when analyzed the data showed by Ferrão-Filho et al. (2010), the $\mathrm{EC}_{50}$ values for Daphnia pulex and Moina micrura Kurz, 1875 exposed to CYRF-01 were not so far off from our data, with $D$. pulex exhibiting near equal sensibility to CYRF-01 as $M$. spinosa Prata did to ITEP-A1. Therefore, these data showed us that sensitivity of different cladoceran species or clones to STXproducing cyanobacteria can vary, either by intrinsic differences on tolerance or because different strains may display differences in their toxin profile and total amount of metabolites, which affects the relative toxicity. Also, we cannot disregard the potential

Table 1. Half maximal effective concentration values $\left(\mathrm{EC}_{50}-48 \mathrm{~h}\right)$ and $95 \%$ confidence intervals (CI) estimated for both clones of $M$. spinosa.

\begin{tabular}{|c|c|}
\hline Test organism & $\begin{array}{c}\mathrm{EC}_{50}-48 \mathrm{~h}(95 \% \mathrm{CI}) \\
\mu \mathrm{gC} \mathrm{L} \mathrm{L}^{-1}\end{array}$ \\
\hline Macrothrix spinosa (Duas & $359.27(323.37-399.16)$ \\
\hline \multicolumn{2}{|l|}{ Unas) } \\
\hline Macrothrix spinosa (Prata) & $188.99(73.83-483.75)$ \\
\hline
\end{tabular}


Table 2. Half maximal effective concentration values $\left(\mathrm{EC}_{50}\right)$ obtained from the literature of cladocerans exposed to saxitoxin-producing strains of Raphidiopsis raciborskii.

\begin{tabular}{|c|c|c|c|c|}
\hline Test organism & Parameters & $\mathrm{EC}_{50}\left(\mu \mathrm{gC} \mathrm{L^{-1 } )}\right.$ & $\mathrm{EC}_{50}\left(\right.$ cell $\left.\mathrm{mL}^{-1}\right)$ & Reference \\
\hline $\begin{array}{l}\text { Macrothrix } \\
\text { spinosa }\end{array}$ & $\begin{array}{c}\text { Immobilization } \\
-48 \mathrm{~h}\end{array}$ & $\begin{array}{c}359.27(323.37 \\
-399.16)\end{array}$ & 3,930 & Present study \\
\hline $\begin{array}{l}\text { Macrothrix } \\
\text { spinosa }\end{array}$ & $\begin{array}{c}\text { Immobilization } \\
-48 \mathrm{~h}\end{array}$ & $\begin{array}{c}188.99(73.83- \\
483.75)\end{array}$ & 2,607 & Present study \\
\hline Daphnia similis & $\begin{array}{c}\text { Immobilization } \\
-48 \mathrm{~h}\end{array}$ & - & $302.56 \times 10^{3}$ & $\begin{array}{l}\text { Zagatto et al. } \\
\quad \text { (2012) }\end{array}$ \\
\hline Daphnia similis & $\begin{array}{c}\text { Immobilization } \\
-48 \mathrm{~h}\end{array}$ & - & $0.218 \times 10^{3}$ & $\begin{array}{l}\text { Zagatto et al. } \\
\quad \text { (2012) }\end{array}$ \\
\hline Daphnia similis & $\begin{array}{c}\text { Immobilization } \\
-2 \mathrm{~h}\end{array}$ & $\begin{array}{l}31.5(13.8- \\
\quad 48.0)\end{array}$ & - & $\begin{array}{l}\text { Ferrão-Filho } \\
\text { et al. (2014b) }\end{array}$ \\
\hline Moina micrura & $\begin{array}{c}\text { Immobilization } \\
-2-3 \mathrm{~h}\end{array}$ & - & 8,905 & $\begin{array}{l}\text { Ferrão-Filho } \\
\text { et al. (2010) }\end{array}$ \\
\hline Daphnia pulex & $\begin{array}{c}\text { Immobilization } \\
-2-3 \mathrm{~h}\end{array}$ & - & 2,133 & $\begin{array}{l}\text { Ferrão-Filho } \\
\text { et al. (2010) }\end{array}$ \\
\hline
\end{tabular}

variation among experimental designs. Those differences, even small, allow some variation in sensitivity.

Saxitoxin-producing cyanobacteria are usually reported as affecting swimming behavior of freshwater zooplankton by decreasing mobility and activity parameters (time spent swimming and resting, distance traveled, and mean velocity) (Ferrão-Filho et al., 2008; 2014b). Saxitoxins can exert acute effects on zooplankton such as paralyze limbs, inhibit thoracic appendages beating, besides reducing the post-abdominal rejection of undesirable particles (Ferrão-Filho et al., 2008; 2014b). Most recently Ferrão-Filho \& Silva (2020) evidenced that neurotoxic cyanobacteria can reduce Daphnia's heartbeat. Indeed, that result is in line with saxitoxins effects once these toxins also block calcium channels (Wiese et al., 2010) which are abundant in the cardiac muscle.

Bibliographic survey allowed to evidence that most of data produced on STX-producing cyanobacteria impact on zooplankton focused on chronic effects such as growth, survivorship and reproduction (Soares et al., 2009; Costa et al., 2013; Ferrão-Filho et al., 2014a; Ferrão-Filho et al., 2019). Therefore, the lack of investigations regarding the acute toxicity of STX-producing cyanobacteria to freshwater zooplankton, especially those of the Macrothricidae family, limits a more in-depth, extensive comparison in our study. Moreover, once STX-producing $R$. raciborskii is up to date reported to South America, most of the studies concentrates in this area, although still incipient. However, considering that $R$. raciborskii is an opportunistic and potentially-toxic species which has dominated in waterbodies from different regions and more recently spread to temperate zones, it is important to produce data on its early impacts on aquatic biota in order to predict future environmental outbreaks as well as subsidize monitoring programs on water quality.

Besides zooplankton sensitivity, cyanobacterial toxicity also depends on the composition of secondary metabolites, such as known cyanotoxins and other non-characterized molecules, as well as their specific cell content. Several of these secondary metabolites are shown to be toxic to plants, invertebrates and vertebrates (Huisman et al., 2018) and, considering the same strain can produce more than one toxic metabolite, it becomes difficult to link the adverse effects to one single known toxin (Ferrão-Filho et al., 2011).

There are substantial differences between the sensibilities of different bioindicator species (Ferrão-Filho et al., 2017). Body length (surface area/volume ratio), having a more selective diet and metabolic differences are some of the characteristics interfering on the effects of toxicants in the organism, and can be limiting factors when choosing a bioindicator species for water monitoring assessments (Costa et al., 2013; Ferrão-Filho et al., 2011; 2014; Gustafsson et al., 2004). However, geographical differences also play a part in a species' sensitivity (Araújo et al., 2008). In some studies, autochthonous tropical species have demonstrated higher sensitivity to certain compounds than their temperate counterparts (Moreira et al., 2014; Moreira et al., 2017), which leads to an increasing interest in the use of native species in ecotoxicological assessments, as the results tend to be more representative of local impacts (Araújo et al., 2008). Despite this, water quality assessments in tropical regions are still mostly based on methods developed in temperate regions, which may diminish the ecological relevance of results (Araújo et al., 2008; Moreira et al., 2014).

The obtained results also revealed that the two clones of $M$. spinosa isolated from different locations were differently affected by $R$. raciborskii metabolites (Table 1). Curiously, the clone isolated from the eutrophic lake with previous occurrence of cyanobacterial blooms seems to be more tolerant to $R$. raciborskii. It is suggested that $M$. spinosa Duas Unas which has previously experienced cyanobacteria, may have evolved tolerance along generations. Chislock et al. (2019) evidenced that clones of Daphnia pulicaria from eutrophic lakes tend to have higher growth rates and survival when 
fed toxic cyanobacteria than populations from oligotrophic environments where cyanobacteria are less abundant. Besides species-specific traits, intraspecific (clonal) particularities should also be taken into consideration. In our study we used two clones of the same species, however the differences in tolerance to toxic dietary cyanobacteria could be linked to their dietary history in their respective sampling locations as hypothesized by Hairston et al. (2001).

In addition, small-size zooplankton generally represents the size spectra predominant under cyanobacterial dominance. Studies show that different body length among Daphnia spp. clones, as well as predation rate, promote different responses to filamentous cyanobacteria (Gilbert et al., 1990; Spitze, 1992). However, when considering the changes in zooplankton structure along bloom establishment, clonal differences are probably as large as those among species, and therefore as important for community structure (Hietala et al., 1995).

According to Ortiz-Rodríguez et al. (2012), exposure of the parental generation to certain substances results in more tolerance from future generations. Gustafsson et al. (2004), for instance, revealed that parts of D. magna populations that had been pre-exposed to toxic cyanobacteria Microcystis aeruginosa had a higher tolerance manifested as higher survivorship even under cyanobacterial food than those populations that were not pre-exposed. Results from Sarnelle et al. (2005) also indicated that D. pulicaria clones isolated from eutrophic lakes were less inhibited by toxic Microcystis than $D$. pulicaria isolated from oligotrophic lakes.

This phenomenon is suggested as a result of natural selection driving adaptation to cyanobacteria producing toxic or inhibitory compounds (Sarnelle et al., 2005). When facing water bodies with recurring toxic cyanobacterial blooms, selection may act on zooplanktonic grazers and favor those that evolve resistance to the compounds and are best able to survive, grow, and reproduce (Ferrão-Filho et al., 2011; Hairston et al., 2001; Sarnelle et al., 2005).

In Daphnia, many adaptive responses, such as responses to dietary changes in the environment, are maternally transferred to the next generation (Schwarzenberger et al., 2013). Hairston et al. (1999) revealed these short-term evolutionary adaptations in Daphnia to an hepatotoxinproducing cyanobacterial strain, but no studies have reported this effect stimulated by saxitoxin-producing cyanobacteria, hence the need of future studies to thoroughly analyze these transgenerational effects on the latter.

Nevertheless, it is likely that a disparity in sensibility between Duas Unas and Prata clones of M. spinosa comes from the fact that Duas Unas Reservoir is a eutrophic environment, with recorded R. raciborskii blooms occurrence, while Prata lake does not show any recorded bloom. It is presumed that previous exposition to cyanobacterium and its metabolites resulted in transgenerational adaptations, justifying the neonates from Prata lake being two times more sensible than those from Duas Unas.

The obtained results reinforce the importance of analyzing whether the test organisms had previous contact with toxicants in their natural environments, seeing that a correlation can be made between tolerance of toxic cyanobacteria by $M$. spinosa and prevalence of cyanobacteria in their habitat. Difference in sensitivity between species and clones of the species is definitely important to factor in when choosing test-organisms in ecotoxicological assays, once transgenerational heritage (rapid evolutionary events) seemingly has great influence in bioindicators' responses to toxicants. Besides, the use of ecologically-relevant testsubjects benefits tropical ecotoxicology, as it prospects tropical standardization and the responses are more relevant to the regions. Furthermore, despite of the difference among clones, native Macrothricidae have shown to be sensitive model organisms and have the potential for biomonitoring toxic cyanobacterial blooms in tropical reservoirs.

\section{ACKNOWLEDGEMENTS}

The authors would like to acknowledge the National Research Council (CNPq) for the PhD scholarship and research grant provided to M.C.P.V and S.M.F.O.A., respectively, and the anonymous reviewers for the valuable suggestions on improving this work.

We also thank Dr. Renato Molica (Federal Rural University of Pernambuco) for kindly provide the cyanobacterial strain used in this study and Alane S. A. Santos (Laboratory of Phycology, Federal Rural University of Pernambuco) for kindly provide $M$. spinosa clones used in this study.

\section{REFERENCES}

ABNT (Associação Brasileira de Normas Técnicas). 2016. Ecotoxicologia aquática - Toxicidade aguda - Método de ensaio com Daphnia spp (Crustacea, Cladocera), Norma ABNT-NBR 12713, Rio de Janeiro. 27p.

ANDERSON, D.M., ALPERMANN, T.J., CEMBELLA, A.D., COLLOS, Y., MASSERET, E., MONTRESOR, M. 2012. The globally distributed genus Alexandrium: multifaceted roles in marine ecosystems and impacts on human health. Harmful Algae, 14:10-35. https://doi.org/10.1016/j.hal.2011.10.012

AGUILERA, A., BERRENDERO-GÓMEZ, E., KASTOVSKY, J., ECHENIQUE, R.O., SALERNO, G.L. 2018. The polyphasic analysis of two native Raphidiopsis isolates supports the unification of the genera Raphidiopsis and Cylindrospermopsis (Nostocales, Cyanobacteria). Phycologia, 57 (2): 130 - 146 https://doi.org/10.2216/17-2.1

ALMEIDA V.L.S., MELÃO, M.G.G., MOURA, A.N. 2012. Plankton diversity and limnological characterization in two shallow tropical urban reservoirs of Pernambuco State, Brazil. An. Acad. Bras. Ciênc., 84 (2) 537 - 550. http://dx.doi.org/10.1590/S0001-37652012005000027

ANTUNES, J.T., LEÃO, P.N., VASCONCELOS, V. 2015. Cylindrospermopsis raciborskii: Distribution, phylogeography and ecophysiology of a global invasive species. Front. Microbiol. 6: 473. https://doi.org/10.3389/fmicb.2015.00473

ARAÚJO, C.V.M., COHIN-DE-PINHO, S.J., CHASTINET, C.B.A., DELGADO SANTANA, F., DA SILVA, E.M. 2008. Potential of the tropical cladocerans Latonopsis australis Sars, 1888 and Macrothrix elegans Sars, 1901 as biomonitors of an acidic lake. Acta Limnol. Bras., 20(2): 111 - 118. 
BURFORD, M.A., BEARDALL, J., WILLIS, A., ORR, P.T., MAGALHÃES, V.F., RANGEL, L.M., AZEVEDO, S.M.F.O., NEILAN, B.A. 2016. Understanding the winning strategies used by the bloom-forming cyanobacterium Cylindrospermopsis raciborskii. Harmful Algae. 54: 44 - 53. https://doi.org/10.1016/j. hal.2015.10.012

BITTENCOURT-OLIVEIRA, M.C., PICCIN-SANTOS, V., MOURA, A.N., ARAGÃO-TAVARES, N.K.C., CORDEIROARAÚJO, M.K. 2014. Cyanobacteria, microcystins and cylindrospermopsin in public drinking supply reservoirs of Brazil. An. Acad. Bras. Ciênc., 86 (1). http://dx.doi.org/10.1590/00013765201302512

BOUVY, M., PAGANO, M., TROUSELLIER, M. 2001. Effects of a cyano-bacterial bloom (Cylindrospermopsis raciborskii) on bacteria and zoo-plankton communities in Ingazeira Reservoir (northeast Brazil). Aquat. Microb. Ecol., 25: 215 - 227. http:// dx.doi.org/10.3354/ame025215

CHISLOCK, M.F., KAUL, K.A., DURHAM, K.A., SARNELLE, O., WILSON, A.E. 2019. Eutrophication mediates rapid clonal evolution in Daphnia pulicaria. Freshw. Biol. 64: 1275 - 1283. http://dx.doi.org/10.1111/fwb.13303

COSTA, I.A.S., AZEVEDO, S.M.F.O., SENNA, P.A.C., BERNARDO, R.R., COSTA, S.M., CHELLAPPA, N.T. 2006. Occurrence of toxin-producing Cyanobacteria blooms in a Brazilian semi-arid reservoir. Braz. J. Biol., 66(1B): 211 - 219. http://dx.doi.org/10.1590/S1519-69842006000200005

COSTA, S.M, FERRÃO-FILHO, A.S., AZEVEDO, S.M.F.O. 2013. Effects of saxitoxin and non-saxitoxin-producing strains of the cyanobacterium Cylindrospermopsis raciborskii on the fitness of temperate and tropical cladocerans. Harmful Algae, 28: 55 - 63. https://doi.org/10.1016/j.hal.2013.05.017

DUMONT, H.J., BRIANO M.S., SUBHASH BABU, K.K. 2002. A reevaluation of the Macrothrix rosea-triserialis group, with the description of two new species (Crustacea: Anomopoda: Macrothricidae). Hydrobiologia, 467: 1 - 44. https://doi. org/10.1023/A:1014933227259

ELMOOR-LOUREIRO, L.M.A. 2007. Phytophilous cladocerans (Crustacea, Anomopoda and Ctenopoda) from Paraná River Valley, Goiás, Brazil. Rev. Bras. Zool., 24(2): 344 - 352. http://dx.doi.org/10.1590/S0101-81752007000200012

FERRÃO-FILHO, A.S. 2009. Bioacumulação de Cianotoxinas e seus efeitos em organismos Aquáticos. Oecol. Bras., 13(2): 272 - 312. http://dx.doi.org/10.4257/oeco.2009.1302.05

FERRÃO-FILHO, A.S., SOARES, M.C.S., MAGALHÃES, V.F., AZEVEDO, S.M.F.O. 2010. A rapid bioassay for detecting saxitoxins using a Daphnia acute toxicity test. Environ. Pollut., 158: 2084 - 2093. https://doi.org/10.1016/j.envpol.2010.03.007

FERRÃO-FILHO, A.S., KOZLOWSKY-SUZUKI, B. 2011. Cyanotoxins: Bioaccumulation and Effects on Aquatic Animals. Mar. Drugs, 9(12): 2729 - 2772. https://doi.org/10.3390/ md9122729

FERRÃO-FILHO, A.S., GALVÃO, L.E.C., MAGALHÃES, V.F. 2014a. Differential susceptibility of cladoceran species to a saxitoxin-producer strain of Cylindrospermopsis raciborskii (cyanobacteria). Ecotoxicology and Environmental Contamination, 9: $33-41$. http://dx.doi.org/10.5132/ eec.2014.01.005

FERRÃO-FILHO, A.S., SOARES, M.C.S., LIMA, R.S., MAGALHÃES, V.F. 2014b. Effects of Cylindrospermopsis raciborskii (cyanobacteria) on the swimming behavior of Daphnia (cladocera). Environ. Toxicol. Chem., 33(1): 223 - 229. https://doi.org/10.1002/etc. 2420

FERRÃO-FILHO, A.S., SILVA, D.A.S., OLIVEIRA, T.A., MAGALHÃES, V.F., PFLUGMACHER, S., SILVA, E.M.
2017. Single and combined effects of microcystins and saxitoxins producer cyanobacteria on the fitness and antioxidant defenses of cladocerans. Environ. Toxicol. Chem., 36(10): 2689 - 2697. https://doi.org/10.1002/etc.3819

FERRÃO-FILHO, A.S., DIAS, T.M., PEREIRA, U.J., DOS SANTOS, J.A.A., KOZLOWSKY-SUZUKI, B. 2019. Nutritional and toxicity constraints of phytoplankton from a Brazilian reservoir to the fitness of cladoceran species. Environ. Sci. Pollut. R., 26: 12881-12893. https://doi.org/10.1007/s11356019-04851-6

FERRÃO-FILHO, A.S., SILVA, D.A.C. 2020. Saxitoxin-producing Raphidiopsis raciborskii (Cyanobacteria) inhibits swimming and physiological parameters in Daphnia similis. Science of the Total Environment, 706: 135751. https://doi.org/10.1016/j. scitotenv.2019.135751

FREITAS, E.C., ROCHA, O. 2011. Acute Toxicity Tests with the Tropical Cladoceran Pseudosida ramosa: The Importance of Using Native Species as Test Organisms. Arch. Environ. Contam. Toxicol., 60: 241 - 249. https://doi.org/10.1007/s00244-010-9541-2

FUENTES-REINES, J.M., ELMOOR-LOUREIRO, L.M.A., GRANADOS-MARTINEZ, C.E. 2018. New records of Cladocera (Crustacea: Branchiopoda) from the Tomo River, Vichada, Colombia. Nauplius, 26. https://doi.org/10.1590/23582936e 2018006

FUENTES-REINES, J.M., ELMOOR-LOUREIRO, L.M.A. 2015. Annotated checklist and new records of Cladocera from the Ciénaga El Convento, Atlántico-Colombia. Pan-American Journal of Aquatic Sciences, 10(3): 189 - 202.

GILBERT, J.J., DURAND, M. W. 1990. Effect of Anabaena flos aquae on the abilities of Daphnia and Keratella to feed and reproduce on unicellular algae. Freshwater Biol., 24: 577 - 596. https://doi.org/10.1111/j.1365-2427.1990.tb00734.x

GUEDES, I.A., RACHID, C.T.C.C., RANGEL, L.M., SILVA, L.H.S., BISCH, P.M., AZEVEDO S.M.F.O., PACHECO, A.B.F. 2018. Close Link Between Harmful Cyanobacterial Dominance and Associated Bacterioplankton in a Tropical Eutrophic Reservoir. Front Microbiol., 12 (9): 424. https://doi.org/10.3389/ fmicb.2018.00424

GUSTAFSSON, S., HANSSON, L. 2004. Development of Tolerance Against Toxic Cyanobacteria in Daphnia. Aquat. Ecol., 38: $37-$ 44. https://doi.org/10.1023/B:AECO.0000020985.47348.5e

HAIRSTON, N.G., HOLTMEIER, C.L., LAMPERT, W., WEIDER, L.J., POST, D. M., FISCHER, J.M., CÁCERES, C.E., FOX, J.A., GAEDKE, U. 2001. Natural selection for grazer resistance to toxic cyanobacteria: evolution of phenotypic plasticity? Evolution, 55: 2203 - 2214. https://doi.org/10.1111/j.0014-3820.2001. tb00736.x

HAIRSTON, N.G., LAMPERT W., CÁCERES, C.E., HOLTMEIER, C.L., WEIDER, L.J., GAEDKE, U., FISCHER, J.M., FOX, J.A., POST, D.M. 1999. Rapid evolution revealed by dormant eggs. Nature, 401: 446. https://doi.org/10.1038/46731

HAMILTON, M.A., RUSSO, R.C., THURFTON, R.B. 1977. Trimmed Spearman-Karber methods for estimating median lethal concentration in toxicity bioassay. Environ. Sci. Technol., 11: 714-719. http://dx.doi.org/10.1021/es60130a004

HAVENS, K.E., EAST, T.L. 2006. Plankton Food Web Responses to Experimental Nutrient Additions in a Subtropical Lake. The Scientific World Journal, 6: 827 - 833. https://doi.org/10.1100/ tsw.2006.176

HIETALA, J., REINIKAINEN, M., WALLS, M. 1995. Variation in life history responses of Daphnia to toxic Microcystis aeruginosa. J. Plankton Res., 17 (12): 2307 - 2318. https://doi. org/10.1093/plankt/17.12.2307

HILLEBRAND, H., DÜRSELEN, C., KIRSHTEL, D., 
POLLINGHER, U., ZOHARY, T. 1999. Biovolume calculation for pelagic and benthic microalgae. J. Phycol., 35: 403 - 424. https://doi.org/10.1046/j.1529-8817.1999.3520403.x

HUISMAN, J., CODD, G.A., PAERL, H.W., IBELINGS, B.W., VERSPAGEN, J.M.H., VISSER, P.M. 2018. Cyanobacterial blooms. Nat. Rev. Microbiol., 16 (8): 471 - 483. https://doi. org/10.1038/s41579-018-0040-1

LEONARD, J.A., PAERL, H.W. 2005. Zooplankton community structure, micro-zooplankton grazing impact, and seston energy content in the St. Johns river system, Florida as influenced by the toxic cyanobacterium Cylindrospermopsis raciborskii. Hydrobiologia, 537: 89 - 97. https://doi.org/10.1007/s10750004-2483-9

LORENZI, A.S., CORDEIRO-ARAÚJO, M.K., CHIA, M.A., BITTENCOURT-OLIVEIRA, M.C. 2018. Cyanotoxin contamination of semiarid drinking water supply reservoirs. Environ. Earth Sci., 77: 595. https://doi.org/10.1007/s12665018-7774-y

LÜRLING, M. 2003. Effects of Microcystin-Free and MicrocystinContaining Strains of the Cyanobacterium Microcystis aeruginosa on Growth of the Grazer Daphnia magna. Environ Toxicol.,18 (3): 202 - 210. https://doi.org/10.1002/tox.10115

MOREIRA, R.A., DAAM, M.A., VIEIRA, B.H., SANCHES, A.L.M., REGHINI, M.V., MANSANO, A.S., FREITAS, E.C., ESPINDOLA, E.L.G., ROCHA, O. 2017. Toxicity of abamectin and difenoconazole mixtures to a Neotropical cladoceran after simulated run-off and spray drift exposure. Aquatic Toxicol., 185: 58 - 66. https://doi.org/10.1016/j.aquatox.2017.02.001

MOREIRA, R.A., MANSANO, A.S., DA SILVA, L.C., ROCHA, O. 2014. A comparative study of the acute toxicity of the herbicide atrazine to cladocerans Daphnia magna, Ceriodaphnia silvestrii and Macrothrix flabelligera. Acta Limnol. Bras., 26(1): $1-8$. http://dx.doi.org/10.1590/S2179-975X2014000100002

MOWE, M.A.D., MITROVIC, S.M., LIM, R.P., FUREY, A., YEO, D.C.J. 2015. Tropical cyanobacterial blooms: a review of prevalence, problem taxa, toxins and influencing environmental factors. J. Limnol., 74(2): 205 - 224. https://doi.org/10.4081/ jlimnol.2014.1005

ORTIZ-RODRÍGUEZ, R., DAO, T.S., WIEGAND, C. 2012. Transgenerational effects of microcystin-LR on Daphnia. J. Exp. Biol., 215: 2795 - 2805. https://doi.org/10.1242/jeb.069211

OSHIMA, Y. 1995. Postcolumn derivatization liquid chromatographic method for paralytic shellfish toxins. J. AOAC Intern., 78: 528532.

PAERL, H.W., HUISMAN, J. 2009. Climate change: a catalyst for global expansion of harmful cyanobacterial blooms. Environ Microbiol Rep., 1 (1): 27 - 37. https://doi.org/10.1111/j.17582229.2008.00004.x

ROCHA, O., DUNCAN, A. 1985. The relationship between cell carbon and cell volume in freshwater algal species used in zooplanktonic studies. J. Plankton Res., 7 (2): 279 - 294. https:// doi.org/10.1093/plankt/7.2.279

SARNELLE, O., WILSON, A.E. 2005. Local adaptation of Daphnia pulicaria to toxic cyanobacteria. Limnol. Oceanogr., 50 (5): 1565 - 1570. https://doi.org/10.4319/lo.2005.50.5.1565

SCHWARZENBERGER, A., SADLER, T., MOTAMENY, S., BEN-KHALIFA, K., FROMMOLT, P., ALTMÜLLER, J., KONRAD, K., VON ELERT, E. 2014. Deciphering the genetic basis of microcystin tolerance. BMC Genomics, 15: 776. https:// doi.org/10.1186/1471-2164-15-776
SCHWARZENBERGER, A., VON ELERT, E. 2013. Cyanobacterial protease inhibitors lead to maternal transfer of increased protease gene expression in Daphnia. Oecologia, 172: 11. https://doi.org/10.1007/s00442-012-2479-5

SCHWARZENBERGER, A., KUSTER, C.J., VON ELERT, E. 2012. Molecular mechanisms of tolerance to cyanobacterial protease inhibitors revealed by clonal differences in Daphnia magna. Mol Ecol, 21: 4898 - 4911. https://doi.org/10.1111/ j.1365-294X.2012.05753.x

SOARES, M.C., LÜRLING, M., PANOSSO, R., HUSZAR, V. 2009. Effects of the cyanobacterium Cylindrospermopsis raciborskii on feeding and life-history characteristics of the grazer Daphnia magna. Ecotoxicol. Environ. Saf., 72(4): 1183 - 1189. https:// doi.org/10.1016/j.ecoenv.2008.09.004

SOARES, C.E.A., ELMOOR-LOUREIRO, L.M.A. An updated checklist of Cladocera (Crustacea: Branchiopoda) from Pernambuco State, Brazil. Biota Neotrop., 11 (2). http://dx.doi. org/10.1590/S1676-06032011000200038

SOARES, M.C.S., HUSZAR, V.L.M., MIRANDA, M.N., MELLO, M.M., ROLAND, F., LÜRLING, M. 2013. Cyanobacterial dominance in Brazil: Distribution and environmental preferences. Hydrobiologia, 717: 1 - 12. https://doi.org/10.1007/s10750-0131562-1

SOTERO-SANTOS, R.B., SILVA, C.R.S.E., VERANIB, N.F., NONAKAC, K.O., ROCHA, O. 2006. Toxicity of a cyanobacteria bloom in Barra Bonita Reservoir (Middle Tietê River, São Paulo, Brazil). Ecotox. Environ. Safe., 64: 163 - 170. https://doi.org/10.1016/j.ecoenv.2005.03.011

SOUSA, F.D.R., ELMOOR-LOUREIRO, L.M.A., MENDONÇAGALVÃO, L., PANARELLI, E., FERREIRA-ARRUDA, T., FAGUNDES, B.G. 2018. Cladoceran (Crustacea: Branchiopoda) biodiversity of protected areas in a Brazilian hotspot. Invertebrate Zoology, 15(3): 309 - 322.

SPITZE, K. 1992. Predator-Mediated Plasticity of Prey Life-History and Morphology - Chaoborus americanus Predation on Daphnia pulex. Am. Nat., 139 (2). https://doi.org/10.1086/285325

TOLLRIAN, R. 1993. Neckteeth formation in Daphnia pulex as an example of continuous phenotypic plasticity: morphological effects of Chaoborus kairomone concentration and their quantification. J. Plankton Res., 15 (11): 1309 - 1318. https:// doi.org/10.1093/plankt/15.11.1309

USEPA (U.S. Environmental Protection Agency). Methods for measuring the acute toxicity of effluents and receiving waters to freshwater and marine organisms. EPA-821-R-02-1. 5th Editon. Washigton. U.S.A, 2002.

VILAR, M.C.P., ARAÚJO-CASTRO, C.M.V., MOURA, A.N. 2014. Acute toxicity of Microcystis spp. (Cyanobacteria) bloom on Moina minuta (Cladocera) in a tropical reservoir, Northeastern Brazil. Ecotoxicology and Environmental Contamination, 9(1): 93-98. https://doi.org/10.5132/eec.2014.01.012

WIESE, M., D’AGOSTINO, P.M., MIHALI, T.K., MOFFITT, M.C., NEILAN, B.A. 2010. Neurotoxic alkaloids: saxitoxin and its analogs. Marine drugs, 8 (7): 2185 - 2211. https://doi. org/10.3390/md8072185

ZAGATTO, P.A., BURATINI S.A., ARAGÃO M., FERRÃOFILHO, A.S. 2012. Neurotoxicity of two Cylindrospermopsis raciborskii strains to mice, Daphnia and fish. Environ Toxicol

Chem 31: 857 - 862. https://doi.org/10.1002/etc.1759. 